Schooling for the Dole? 


\section{YOUTH QUESTIONS}

Series Editors: Philip Cohen and Angela McRobbie

This series sets out to question the ways in which youth has traditionally been defined by social scientists and policy-makers, by the caring professions and the mass media, as well as in 'commonsense' ideology. It explores some of the new directions in research and practice which are beginning to challenge existing patterns of knowledge and provision. Each book examines a particular aspect of the youth question in depth. All of them seek to connect their concerns to the major political and intellectual debates that are now taking place about the present crisis and future shape of our society. The series will be of interest to those who deal professionally with young people, especially those concerned with the development of socialist, feminist and anti-racist perspectives. But it is also aimed at students and general readers who want a lively and accessible introduction to some of the most awkward but important issues of our time.

\section{Published}

Inge Bates, John Clarke, Philip Cohen, Dan Finn, Robert Moore and Paul Willis

SCHOOLING FOR THE DOLE?

The New Vocationalism

Angela McRobbie and Mica Nava (eds)

GENDER AND GENERATION

\section{Forthcoming}

Philip Cohen and Harwant Bains (eds)

MULTI-RACIST BRITAIN

Philip Cohen and Graham Murdock (eds)

THE MAKING OF THE YOUTH QUESTION

Andrew Dewdney and Martin Lister

YOUTH PHOTOGRAPHY

\section{Dan Finn}

TRAINING WITHOUT JOBS:

From the Raising of the School-Leaving Age to the New Training Initiative 


\title{
Schooling for the Dole?
}

\author{
The New Vocationalism
}

\author{
Inge Bates, John Clarke, Philip Cohen, \\ Dan Finn, Robert Moore and Paul Willis
}

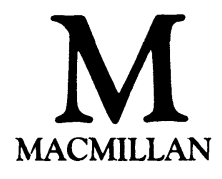


(C) Inge Bates, John Clarke, Philip Cohen, Dan Finn, Robert Moore and Paul Willis 1984

Softcover reprint of the hardcover 1st edition 1984

All rights reserved. No part of this publication

may be reproduced or transmitted, in any form

or by any means, without permission

First published 1984 by

Higher and Further Education Division

MACMILLAN PUBLISHERS LTD

Houndmills, Basingstoke, Hampshire, RG21 2XS, and London

Companies and representatives

throughout the world

\author{
Typeset by \\ Wessex Typesetters Ltd \\ Frome, Somerset
}

British Library Cataloguing in Publication Data

Schooling for the dole

1. Curriculum planning-Great Britain

2. Unemployment-Great Britain

I. Bates, Inge

375'.00941 LB1564.G7

ISBN 978-0-333-36729-2 ISBN 978-1-349-17581-9 (eBook)

DOI 10.1007/978-1-349-17581-9 


\section{Contents}

List of Tables vi

Preface vii

1 Introduction 1

John Clarke and Paul Willis

2 Leaving School and Growing Up: Work Experience in the Juvenile Labour Market Dan Finn

3 Schooling and the World of Work 65

Robert Moore

4 Against the New Vocationalism 104

Philip Cohen

5 From Vocational Guidance to Life Skills: Historical Perspectives on Careers Education

Inge Bates

6 Conclusion: Theory and Practice 220

Paul Willis

Author and Name Index $\quad 229$

$\begin{array}{ll}\text { Subject Index } & 232\end{array}$ 


\section{List of Tables}

2.1 Young people surveyed by sex, school and qualifications

2.2 The jobs they wanted or expected to get 30

2.3 When they expected to leave home 32

$2.4 \quad$ Number of part-time jobs held 37

2.5 Methods of obtaining current and last part-time jobs 38

2.6 Reasons for leaving last part-time job 39

2.7 Would they want to do the work full-time? 41

$2.8 \quad$ Nature of jobs held 43

2.9 Principal items of expenditure 48

2.10 Frequency of jobs done around the house 50

2.11 Tasks most frequently done 51

2.12 Numbers having time off school between Xmas and Easter and their reasons

2.13 Where their peer groups come from 55 


\section{Preface}

This book arises out of discussions and collective work in a group of sociologists, researchers and educationalists with an interest in the relationships between school and work. The group was convened by Paul Willis, changed its composition somewhat over time and met in a number of contexts - first under the auspices of a conference organised by the Socialist Teachers Alliance, and subsequently in the framework of a series of workshops financed by the Social Science Research Council on the Transition From School to Work.

The introduction and conclusion are the product of discussion in the group as a whole. In other chapters, although subject in most cases to lengthy collective discussion and analysis, individual contributors have drawn on their own work and express their own views and opinions. Editorial work and decisions were undertaken by the whole group collectively.
I.B.
J.C.
P.C.
D.F.
R.M.
P.W. 